\title{
THE EFFECTS OF DIRECT AND INDIRECT CORRECTIVE FEEDBACKS ON THE STUDENTS' WRITING COMPETENCY
}

\author{
P. I. K. S. Mahendra ${ }^{1}$, D. K. Tantra', I. W. Suarnajaya ${ }^{2}$ \\ ${ }^{123}$ English Language Education, Post Graduate Program, Universitas Pendidikan Ganesha, Singaraja \\ e-mail: sriyogimahendra@gmail.com, komang.tantra@pasca.undiksha.ac.id, \\ wayan.suarnajaya@pasca.undiksha.ac.id
}

The research objectives are 1) to prove the significant effects of direct and indirect corrective feedbacks on the students' writing competency, 2) to prove significant differences of the effects of direct and indirect corrective feedbacks on the students' competency in writing descriptive texts and recount texts. These research applied a quasi-experimental design with repeated measures. The sample was recruited from two intact classes using purposive sampling. Prior to conducting the experiment, the writing competency test was administered to measure the students' writing competency across text types. Prior to administration, the instrument was validated for its readability (Readibility $=82.00$ ), reliability (Cronbach alpha=0.98), and content validity (Pearson's=1.00). The obtained data were analyzed descriptively and inferentially. The results show, firstly, there were significant effects of direct and indirect corrective feedbacks on the students' writing competency at SMPN 2 Manggis. However, the effect of direct corrective feedback is more effective than that the indirect corrective feedback. Secondly, there were significant differences of the effects of direct and indirect corrective feedbacks across descriptive texts and recount texts especially on the descriptive text about place and recount text about students' experience. However, the effect of direct corrective feedback is more effective than that the indirect corrective feedback. The results imply the necessity to apply the direct corrective feedback than the indirect corrective feedback when the Junior High School's students write descriptive and recount texts.

\section{Keywords: direct corrective feedback, indirect corrective feedback, and text types.}

\section{INTRODUCTION}

Feedback interventions are reported to have resulted in positive outcomes. Thus they continue to attract attention. One form of feedback interventions is feedback correction that supports students' writing development (Eslami, 2014; Almasi, 2016; Khodareza \& Delvand, 2016; Seiffedin \& El-Sakka, 2017; Chen, 2018). This may explain the large variation in approaches and in the results of such interventions which presents major challenges for educators or researchers who attempt to replicate any given intervention especially in writing at Junior High School (hereafter, JHS). If feedback processes are to be successfully used as an instructional strategy in writing, more clarity is needed in the specific action steps taken to apply behavioral theory to writing indicators.

Good writing skills are highly important for students. Writing is one of the important ways of expressing thoughts and communicating ideas and views to others in written language. In Curriculum 2013, the standard competency in writing that must be mastered is the ability to convey information about a person, animal, and place and the ability to convey information about one's past experience. However, the eighth-grade students of SMP Negeri 2 Manggis still have difficulties with the topics. They still got confused when they wrote a text, especially in determining whether they have to use verb 1 or verb 2 . Besides, the students' competency was low, and one of the causes was a lack of correction that they got from their teacher. Based on the results of the interview on March 2, 2019, conducted to the eighth-grade students and English teachers in SMP Negeri 2 Manggis, it was found that the students had problems in learning to write descriptive and recount text.

Based on the explanation above, improving students' writing competency is an essential factor in learning English as the purpose of Curriculum 2013. One way of doing this is through feedback correction. The proponents of feedback correction claim that using corrective feedback (hereafter, CF) technique can significantly improve students' writing competency (Maleki \& Eslami, 2013). Some researchers then have come up with their findings in reaction 
to this claim (Hyland, 1998; Ferris, 2006; Ellis, et.al.. 2008; Sheen, 2010). They proved that feedback is still needed to be given to the students' writing to improve its quality (Aridah, 2016). To support her finding, Damayanti (2017) claims that the use of indirect corrective feedback to the JHS students in writing descriptive text was positively effective in increasing the students' writing skill in writing a descriptive text. Shirotha (2016) also claims that the use of direct corrective feedback in English as a second language students (ESL) students is satisfying. Furthermore, it is also shown that direct written corrective feedback also elicits students' autonomous learning.

Feedback is effective to improve writing competency whether it is used in JHS students. However, both of the studies did not specifically find out which correction techniques is more effective to help the students to develop their writing competency as specified in Curriculum 2013. SMP Negeri 2 Manggis was chosen because in this school the implementation of the 2013 curriculum has only been done for three years and this is a chance for the researcher to conduct a research to check the effectiveness of the implementation Curriculum 2013. The researcher focuses on the eighth-grade students because the students in this grade had already learned how to write a text in the seventh grade and continued to do so in the eighth grade in learning descriptive and recount texts. In the observation session that has been mentioned in the fifth paragraph, the researcher found a deficiency in the students' writing competency, especially at the eighth-grade. The present research focused on feedback technique in correcting the students' writing to reduce the problems faced by the students in writing based on the writing aspects as that are stated in the 2013 Curriculum, especially in Kemendikbud (2017).

\section{A. Research Problems}

The research objectives are 1) to prove the significant effect of direct and indirect corrective feedbacks on the students' writing competency, 2) to prove significant differences of the effects of direct and indirect corrective feedbacks on the students' competency in writing descriptive texts, and 3) to prove significant differences of the effects of direct and indirect corrective feedbacks on the students' competency in writing recount texts. The research problems include: 1) Are there any significant effects of direct and indirect corrective feedbacks on the students' writing competency at the eighth-grade students of SMP Negeri 2 Manggis? 2) Are there any significant differences of the effects of direct and indirect corrective feedbacks on the students' competency in writing descriptive texts at the eighth-grade students of SMP Negeri 2 Manggis? 3) Are there any significant differences of the effects of direct and indirect corrective feedbacks on the students' competency in writing recount texts at the eighth-grade students of SMP Negeri 2 Manggis?

\section{B. Hypothesis of the study}

1. There are no significant effects of direct and indirect corrective feedbacks on the student's writing competency at the eighth-grade students of SMP Negeri 2 Manggis.

2. There are no significant differences of the effects of direct and indirect corrective feedbacks on student's competency in writing descriptive texts at the eighth-grade students of SMP Negeri 2 Manggis.

3. There are no significant differences of the effects of direct and indirect corrective feedbacks on student's competency in writing recount texts at the eighth-grade students of SMP Negeri 2 Manggis.

Statistically:

a. $H_{0}: \mu_{\text {dcf }}=\mu_{\text {idcf }}=\mu_{\text {ddes }}=\mu_{\text {iddes }}=\mu_{\text {drec }}=\mu_{\text {idrec }}=0$

b. $\mathrm{H}_{\mathrm{a}}: \mu_{\mathrm{dcf}} \neq \mu_{\text {idcf }} \neq \mu_{\text {ddes }} \neq \mu_{\text {iddes }} \neq \mu_{\text {drec }} \neq \mu_{\text {idrec }} \neq 0$ 


\section{RESEARCH METHOD}

The research design used was a quasi-experimental design (Campbell and Stanley, 1963). The design was arranged with different text types, namely descriptive and recount texts. The treatment was repeated for three sessions, namely 1) preparation session, 2) elaboration session, and consolidation session. Therefore, there were 12 sessions at once to find the main effects and differences in effects across two types of text. The repeated sessions 1) preparation, 2) exploration, and 3) consolidation were carried out to ensure the subject's understanding of treatments. The quasi-experimental design is shown in the following figure.

\begin{tabular}{|l|l|l|l|l|l|}
\hline Xfc1pO & X fc1eO & Xfc1cO & Xfc2pO & X fc2eO & Xfc2Co \\
\hline Xufc1pO & X ufc1eO & Xufc1cO & Xufc2pO & Xu fc2eO & $\begin{array}{l}\text { Xufc2C } \\
\text { o }\end{array}$ \\
\hline
\end{tabular}

Figure I

The Quasi-Experimental Design

A population includes all members of a defined group; the sample is a subset of the population; and sampling is a technique of getting a representative portion of a population (Hinkle, et al., 1979). The sampled population included all the eighth-grade students in SMP Negeri 2 Manggis, totaling 156 students. Sample was recruited from two classes for comparative treatments. They were the direct and indirect treatment groups. Both groups were selected using purposive sampling based on the objectives and they were assigned into two different groups memberships (Campbell \& Stanley, 1963).

The current research manipulated one independent variable, that is, corrective feedback with its two levels. The corrective feedbacks consisted of direct and indirect corrective feedbacks. One moderator variable was used to control for differences, they were, two text types. The two text types were descriptive and recount texts. Whereas, the dependent variable was the students' writing competency. The independent variable was of nominal nature. The moderator variable was also of nominal nature. Whilst, the writing competency was measured on interval scale.

A Writing competency test was administered in every experimental session. The students were asked to write two different short descriptive and recount text. There were seven writing indicators included in the writing competency test, namely 1) originality of writing, 2) Appropriateness of Contents with the Title, 3) The Arrangement of the Paragraph, 4) Vocabulary, 5) Grammar, 6) mechanics.

Instrument validation or calibration is a methodological process of developing a readable, reliable, and valid instrument for data collection purposes (Candiasa, 2011). Prior to data collection, the writing competency test was validated for its readability, reliability, and validity. The instrument readability was measured by two independent expert judges who rated the extent to which they could understand the instrument. The readability measure used the percentage of agreement on their comprehension between the two judges (Grondlund, 1985). The aspects, indicators, and descriptors were adapted from Curriculum 2013. The two judges were asked to rate the consistency of the aspects, indicators, and descriptors by scoring as objectively as possible. They had also to give relevant comments or reasons for the given scores.

The two judges were asked how much they both agreed on the contents of the aspects, indicators, and sub-indicators as contained in the instrument. The readability measure used the percentage of agreement on their comprehension between the two judges (Grondlund,1985). The reliability measure used was that of the Cronbach Alpha and the validity measure used was that of the Pearson Product Moment. The instrument readability was $83.85 \%$, with a Cronbach Alpha 0.98. Whilst, the validity was reported very high with agreement index 1.00. This research applied a quasi-experiment with repeated measures and counter-balanced with text types (Campbell and Stanley,1985). The procedures of data collection were based on learning scenarios. The learning scenarios were tried out to students to ensure understanding of the learning activities. 
The obtained data were analyzed statistically in two stages, they are descriptive and inferential analysis. The descriptive statistical analysis was directed to describe the main effects of corrective feedback types across text types on the students' writing competency. The main effects were also tested for statistical significance (Hinkel,et al,1979). The inferential statistical analysis was done using One-Way Anova (Hinkel,et al.,1979: 252-253). The oneway analysis of variance was further analyzed after the rejections of the null hypothesis (Hinkel,et al.,1979:269). The Tukey method was chosen to locate specific difference among the means.

\section{FINDINGS AND DISCUSSION}

\section{The Effects of Corrective Feedbacks on Students' Writing Competency}

After the two techniques were manipulated repeatedly across text types as mentioned previously, the analysis of this experimental research was initially carried out through descriptive Statistical analysis of writing competency of the eight grade of SMPN 2 Manggis based on the experimental group in general and writing competency of each experimental group based on text types. The table analytical data of students' score in writing competency was presented below:

Table 1

Descriptive Statistics of the Students' Writing Competency

\begin{tabular}{|c|c|c|c|c|c|c|c|c|c|c|c|c|c|}
\hline \multirow{3}{*}{ Statistics } & Feedbacks & \multicolumn{6}{|c|}{ Direct Feedback } & \multicolumn{6}{|c|}{ Indirect Feedback } \\
\hline & Text Types & \multicolumn{3}{|c|}{ Descriptive } & \multicolumn{3}{|c|}{ Recount } & \multicolumn{3}{|c|}{ Descriptive } & \multicolumn{3}{|c|}{ Recount } \\
\hline & Sessions & 1 & 2 & 3 & 1 & 2 & 3 & 1 & 2 & 3 & 1 & 2 & 3 \\
\hline \multicolumn{2}{|c|}{ Maximum scores } & 8.00 & 9.00 & 9.70 & 8.00 & 9.00 & 9.70 & 5.70 & 7.00 & 8.00 & 5.70 & 6.70 & 8.00 \\
\hline \multicolumn{2}{|c|}{ Minimum scores } & 6.00 & 7.30 & 8.00 & 6.00 & 7.30 & 8.00 & 4.00 & 5.00 & 6.00 & 4.00 & 5.30 & 6.00 \\
\hline \multicolumn{2}{|c|}{ Mean } & 6.94 & 8.30 & 8.97 & 6.99 & 8.01 & 8.95 & 4.97 & 5.98 & 6.98 & 4.67 & 5.94 & 6.97 \\
\hline \multicolumn{2}{|c|}{ Grand Mean } & \multicolumn{6}{|c|}{8.03} & \multicolumn{6}{|c|}{5.92} \\
\hline \multicolumn{2}{|c|}{ Ranges } & 2.00 & 1.70 & 1.70 & 2.00 & 1.70 & 1.70 & 1.70 & 2.00 & 2.00 & 1.70 & 1.40 & 2.00 \\
\hline \multicolumn{2}{|c|}{ Standard Deviations } & .447 & .459 & .459 & .465 & .447 & .466 & .406 & .481 & .481 & .449 & .416 & .500 \\
\hline \multicolumn{2}{|c|}{ Variances } & .200 & 210 & 211 & 216 & .200 & .217 & .165 & 231 & 231 & 202 & .173 & .250 \\
\hline \multicolumn{2}{|c|}{ Standard Errors } & .086 & .088 & .088 & .089 & .086 & .090 & .078 & .093 & .093 & .086 & .080 & .096 \\
\hline
\end{tabular}

Source: Data analysis of May 2019; SPSSX. v.23

In general, Table 1 shows the descriptive statistics of the two different corrective feedbacks. The explanation of descriptive statistical analysis clearly pointed out that both of the correction feedbacks were significant effects on the students writing competency. However, the mean scores of the group which was treated through the implementation of direct corrective feedback across two text types were consistently higher than the mean scores of indirect corrective feedback group. In terms of the grand mean scores, the grand mean score of direct corrective feedbacks group was 8.03 much higher than the grand mean score of indirect corrective feedback group 5.92. It showed that descriptively direct corrective feedback gave more effects on the students' writing competency. After the descriptive analysis was completed, the analysis proceeded to inferential analysis using One-Way ANOVA. The results are shown in the following table.

Table 2

The One-Way ANOVA Analysis of the Students' Writing Competency

\begin{tabular}{|l|c|c|c|c|c|}
\hline & Sum of Squares & df & Mean Square & F & Sig. \\
\hline Between Groups & 120.026 & 3 & 40.009 & 197.304 & 0.001 \\
Within Groups & 21.089 & 104 & .203 & & \\
Total & 141.115 & 107 & & & \\
\hline
\end{tabular}

Source: Data analysis of May 2019; SPSS 23 
The inferential analysis using One-Way ANOVA shows that there were significant effects of the two corrective feedbacks on students' writing competency $(F=197.3 ; \alpha=0.01$. It was lower than 0.05. It meant that there were significant. The effect of direct corrective feedback was more effective than indirect corrective feedback. Hence, the first hypothesis that states that there are no significant effects on direct corrective feedback and that of indirect corrective feedback on the students' writing competency at the eighth grade of SMP Negeri 2 Manggis was rejected. The result shows that there were significant effects of the two corrective feedbacks on the students' writing competency across text types.

\section{The Effects of Corrective Feedbacks on Descriptive Texts}

When the effects of direct and indirect corrective feedbacks controlled for only the descriptive texts (descriptive text about a person, animal, and place), the resulting descriptive statistics are shown in the following table.

Table 3

Descriptive Statistics of the Students' Writing Competency on descriptive texts

\begin{tabular}{|c|c|c|c|c|c|c|c|}
\hline \multirow{3}{*}{$\begin{array}{l}\text { Statistic } \\
\mathrm{s}\end{array}$} & Feedbacks & \multirow{2}{*}{\multicolumn{3}{|c|}{ Direct Feedback }} & \multirow{2}{*}{\multicolumn{3}{|c|}{$\begin{array}{c}\text { Indirect } \\
\text { Feedback }\end{array}$}} \\
\hline & Texts & & & & & & \\
\hline & Sessions & 1 & 2 & 3 & 1 & 2 & 3 \\
\hline \multicolumn{2}{|c|}{ Maximum scores } & $\begin{array}{l}8.0 \\
0\end{array}$ & $\begin{array}{l}9.0 \\
0\end{array}$ & $\begin{array}{l}9.7 \\
0\end{array}$ & $\begin{array}{l}5.7 \\
0\end{array}$ & $\begin{array}{l}7.0 \\
0\end{array}$ & $\begin{array}{l}8.0 \\
0\end{array}$ \\
\hline \multicolumn{2}{|c|}{ Minimum scores } & $\begin{array}{l}6.0 \\
0\end{array}$ & $\begin{array}{l}7.3 \\
0\end{array}$ & $\begin{array}{l}8.0 \\
0\end{array}$ & $\begin{array}{l}4.0 \\
0\end{array}$ & $\begin{array}{l}5.0 \\
0\end{array}$ & $\begin{array}{l}6.0 \\
0\end{array}$ \\
\hline \multicolumn{2}{|c|}{ Grand Mean } & \multicolumn{3}{|c|}{8.07} & \multicolumn{3}{|c|}{5.97} \\
\hline \multicolumn{2}{|c|}{ Ranges } & $\begin{array}{l}2.0 \\
0\end{array}$ & $\begin{array}{l}1.7 \\
0\end{array}$ & $\begin{array}{l}1.7 \\
0\end{array}$ & $\begin{array}{l}1.7 \\
0\end{array}$ & $\begin{array}{l}2.0 \\
0\end{array}$ & $\begin{array}{l}2.0 \\
0\end{array}$ \\
\hline \multicolumn{2}{|c|}{ Standard Deviations } & $\begin{array}{l}.44 \\
7\end{array}$ & $\begin{array}{l}.45 \\
9\end{array}$ & $\begin{array}{l}.45 \\
9\end{array}$ & $\begin{array}{l}.40 \\
6\end{array}$ & $\begin{array}{l}.48 \\
1\end{array}$ & $\begin{array}{l}.48 \\
1\end{array}$ \\
\hline \multicolumn{2}{|c|}{ Variances } & $\begin{array}{l}.20 \\
0\end{array}$ & $\begin{array}{l}.21 \\
0\end{array}$ & $\begin{array}{l}.21 \\
1\end{array}$ & $\begin{array}{l}.16 \\
5\end{array}$ & $\begin{array}{l}.23 \\
1\end{array}$ & $\begin{array}{l}.23 \\
1\end{array}$ \\
\hline \multicolumn{2}{|c|}{ Standard Errors } & $\begin{array}{l}.08 \\
6\end{array}$ & $\begin{array}{l}.08 \\
8\end{array}$ & $\begin{array}{l}.08 \\
8\end{array}$ & $\begin{array}{l}.07 \\
8\end{array}$ & $\begin{array}{l}.09 \\
3\end{array}$ & $\begin{array}{l}.09 \\
3\end{array}$ \\
\hline
\end{tabular}

Source: Data analysis of May 2019; SPSS 23

In general, Table 3 shows the descriptive statistics of the two different corrective feedbacks. The explanation of descriptive statistical analysis clearly pointed out that both of the correction feedbacks were significant effects on the students' competency in writing descriptive texts. However, the mean score of the group which was treated through the implementation of direct corrective feedback on descriptive text about person, animal, and place was consistently higher than the mean score of indirect corrective feedback group. In terms of the grand mean scores, the grand mean score of direct corrective feedbacks group was (8.07) much higher than the grand mean score of indirect corrective feedback group was (5.97). It showed that descriptively direct corrective feedback gave more effects on the students' competency in writing descriptive texts. After the descriptive analysis was completed, the analysis proceeded to inferential analysis using One-Way ANOVA. The results are shown there were significant differences in the effects of direct and indirect corrective feedbacks on the students' competency in writing descriptive texts and the second hypothesis was rejected. Since the differences in the effects of direct and indirect corrective feedbacks in writing descriptive texts were statistically found significant; thus, the analysis was continued to post hoc test.

The statistical of One-Way ANOVA showed that there were significant differences in the effects of direct and indirect corrective feedbacks on the students' competency in writing 
descriptive texts. Therefore, in order to figure out the significant differences, the post hoc test was then carried out through Multiple Comparison using Tukey HSD (Honestly Significant Difference) test. The result briefly presented as follows.

Table 4

The Multiple Comparison Tukey HSD Analysis of Students' Writing Competency on Descriptive texts

\begin{tabular}{|c|c|c|c|c|c|c|}
\hline $\begin{array}{l}\text { Dependent } \\
\text { Variable }\end{array}$ & $\begin{array}{l}\text { (I) } \\
\text { Experimenta } \\
\text { I Groups }\end{array}$ & $\begin{array}{l}(\mathrm{J}) \\
\text { Experimenta } \\
\text { I Groups }\end{array}$ & $\begin{array}{c}\text { Mean } \\
\text { Difference } \\
(\mathrm{I}-\mathrm{J})\end{array}$ & $\begin{array}{l}\text { Std. } \\
\text { Error }\end{array}$ & Q & Sig. \\
\hline \multirow{6}{*}{$\begin{array}{l}\text { Direct } \\
\text { Descriptive } \\
\text { Text }\end{array}$} & \multirow[t]{2}{*}{ Person } & Animal & $1.35926^{*}$ & $\begin{array}{r}.1238 \\
5\end{array}$ & $10.98^{-}$ & $\begin{array}{r}.00 \\
1\end{array}$ \\
\hline & & Place & $\begin{array}{r}- \\
2.02963^{*}\end{array}$ & $\begin{array}{r}.1238 \\
5 \\
\end{array}$ & 16.39 & $\begin{array}{r}.00 \\
1 \\
\end{array}$ \\
\hline & \multirow[t]{2}{*}{ Animal } & Person & $1.35926^{*}$ & $\begin{array}{r}.1238 \\
5 \\
\end{array}$ & 10.98 & $\begin{array}{r}.00 \\
1 \\
\end{array}$ \\
\hline & & Place & $-.67037^{\star}$ & $\begin{array}{r}.1238 \\
5\end{array}$ & -5.41 & $\begin{array}{r}.00 \\
1\end{array}$ \\
\hline & \multirow[t]{2}{*}{ Place } & Person & $2.02963^{*}$ & $\begin{array}{r}.1238 \\
5 \\
\end{array}$ & 16.39 & $\begin{array}{r}.00 \\
1 \\
\end{array}$ \\
\hline & & Animal & $.67037^{\star}$ & $\begin{array}{r}.1238 \\
5 \\
\end{array}$ & 5.41 & $\begin{array}{r}.00 \\
1 \\
\end{array}$ \\
\hline \multirow{6}{*}{$\begin{array}{l}\text { Indirect } \\
\text { Descriptive } \\
\text { Text }\end{array}$} & \multirow[t]{2}{*}{ Person } & Animal & $1.00370^{*}$ & $\begin{array}{r}.1244 \\
4 \\
\end{array}$ & -8.07 & $\begin{array}{r}.00 \\
1 \\
\end{array}$ \\
\hline & & Place & $\begin{array}{r}- \\
2.00370^{*}\end{array}$ & $\begin{array}{r}.1244 \\
4\end{array}$ & $16.10^{-}$ & $\begin{array}{r}.00 \\
1\end{array}$ \\
\hline & \multirow[t]{2}{*}{ Animal } & Person & $1.00370^{*}$ & $\begin{array}{r}.1244 \\
4 \\
\end{array}$ & 8.07 & $\begin{array}{r}.00 \\
1 \\
\end{array}$ \\
\hline & & Place & $1.00000^{*}$ & $\begin{array}{r}.1244 \\
4 \\
\end{array}$ & -8.04 & $\begin{array}{r}.00 \\
1 \\
\end{array}$ \\
\hline & \multirow[t]{2}{*}{ Place } & Person & $2.00370^{*}$ & $\begin{array}{r}.1244 \\
4\end{array}$ & 16.10 & $\begin{array}{r}.00 \\
1\end{array}$ \\
\hline & & Animal & $1.00000^{\star}$ & $\begin{array}{r}.1244 \\
4\end{array}$ & 8.04 & $\begin{array}{r}.00 \\
1\end{array}$ \\
\hline
\end{tabular}

Source: Data analysis of May 2019; SPSS 23

1. Direct descriptive text about a person versus animal

Based on the results of the Post Hoc tests in the multiple comparisons table above, the mean difference score of direct descriptive text about person and direct descriptive text about animal was (-1.359). It meant that there was a significant difference of the effect of direct corrective feedback on the students' competency in writing a descriptive text about person and descriptive text about animal $(Q=-10.98 ; \alpha=0.01)$.

2. Direct descriptive text about person versus place

Based on the results of the Post Hoc tests in the multiple comparisons table above, the mean difference score of direct descriptive text about person and direct descriptive text about place was (-2.029). It meant that there was a significant difference of direct corrective feedback on the students' competency in writing a descriptive text about person and descriptive text about place $(\mathrm{Q}=-16.39 ; \alpha=0.01)$.

3. Direct descriptive text about animal versus place

Based on the results of the Post Hoc tests in the multiple comparisons table above, the mean difference score of direct descriptive text about animal and direct descriptive text about place was (-0.670). It meant that there was a significant difference of direct corrective feedback on the students' competency in writing a descriptive text about animal and descriptive text about place $(Q=-5.41 ; \alpha=0.01)$.

4. Indirect descriptive text about person versus animal 
Based on the results of the Post Hoc tests in the multiple comparisons table above, the mean difference score of indirect descriptive text about person and indirect descriptive text about animal was (-1.003). It meant that there was a significant difference of the effect of indirect corrective feedback on the students' competency in writing a descriptive text about person and descriptive text about animal $(Q=-8.07 ; \alpha=0.01)$.

5. Indirect descriptive text about person versus place

Based on the results of the Post Hoc tests in the multiple comparisons table above, the mean difference score of indirect descriptive text about person and indirect descriptive text about place was (-2.003). It meant that there was a significant difference of indirect corrective feedback on the students' competency in writing a descriptive text about person and descriptive text about place $(Q=-16.10 ; \alpha=0.01)$.

6 . Indirect descriptive text about animal versus place

Based on the results of the Post Hoc tests in the multiple comparisons table above, the mean difference score of indirect descriptive text about animal and indirect descriptive text about place was (-1.000). It meant that there was a significant difference of indirect corrective feedback on the students' competency in writing a descriptive text about animal and descriptive text about place $(Q=-8.04 ; \alpha=0.01)$.

Based on the result of table 4 above, it can be concluded that there were significant differences of the effects of direct and indirect corrective feedback on the students' competency in writing a descriptive text about person, animal, and place. Besides, the most significant differences were found in the descriptive text about place. It clearly signified that direct and indirect worked well on the students' competency in writing descriptive texts. However, the result of the descriptive analysis showed that direct corrective feedback gave more effect than indirect corrective feedback.

\section{The Effects of Corrective Feedbacks on Recount Texts}

When the effects of direct and indirect corrective feedbacks controlled for only the recount texts (descriptive text about person, animal, and place), the resulting descriptive statistics are shown in the following table.

Table 5

\section{Descriptive Statistics of the Students' Writing competency on recount texts}

\begin{tabular}{|l|c|c|c|c|c|c|c|}
\hline \multirow{3}{*}{ Statistics } & Feedbacks & \multicolumn{3}{|c|}{ Direct Feedback } & \multicolumn{3}{c|}{ Indirect Feedback } \\
\cline { 2 - 8 } & Texts & \multicolumn{3}{|c|}{ Recount } & \multicolumn{3}{c|}{ Recount } \\
\cline { 2 - 8 } & Session & 1 & 2 & 3 & 1 & 2 & 3 \\
\hline Maximum scores & 8.00 & 9.00 & 9.70 & 5.70 & 6.70 & 8.00 \\
\hline Minimum scores & 6.00 & 7.30 & 8.00 & 4.00 & 5.30 & 6.00 \\
\hline Grand Mean & \multicolumn{3}{|c|}{7.98} & & \multicolumn{4}{c|}{5.86} \\
\hline Ranges & 2.00 & 1.70 & 1.70 & 1.70 & 1.40 & 2.00 \\
\hline Standard Deviations & .465 & .447 & .466 & .449 & .416 & .500 \\
\hline Variances & .216 & .200 & .217 & .202 & .173 & .250 \\
\hline Standard Errors & .089 & .086 & .090 & .086 & .080 & .096 \\
\hline
\end{tabular}

\section{Source: Data analysis of May 2019; SPSS 23}

In general, Table 5 shows the descriptive statistics of the two different corrective feedbacks. The explanation of descriptive statistical analysis clearly pointed out that both of the correction feedbacks were significant effects on the students' competency in writing recount texts. However, the mean score of the group which was treated through the implementation of direct corrective feedback on recount text about factual recount, imaginative recount, and students' experience was consistently higher than the mean score of indirect corrective feedback group. In terms of the grand mean scores, the grand mean score of direct corrective feedbacks group was (7.98) much higher than the grand mean score of indirect corrective feedback group was (5.86). It showed that descriptively direct corrective feedback gave more effects on the students' competency in writing recount texts. After the descriptive 
analysis was completed, the analysis proceeded to inferential analysis using One-Way ANOVA. The results are shown there were significant differences in the effects of direct and indirect corrective feedbacks on the students' competency in writing recount texts and the third hypothesis was rejected. Since the differences of the effects of direct and indirect corrective feedbacks in writing recount texts were statistically found significant; thus, the analysis was continued to post hoc test.

The statistical of One-Way ANOVA showed that there were significant differences in the effects of direct and indirect corrective feedbacks on the students' competency in writing recount texts. Therefore, in order to figure out the significant differences, the post hoc test was then carried out through Multiple Comparison using Tukey HSD (Honestly Significant Difference) test. The result briefly presented as follows.

Table 6

The Multiple Comparison Tukey HSD Analysis of Students' Writing Competency on recount texts

\begin{tabular}{|c|c|c|c|c|c|c|}
\hline $\begin{array}{l}\text { Depende } \\
\text { nt } \\
\text { Variable }\end{array}$ & $\begin{array}{l}\text { (I) } \\
\text { Experimenta } \\
\text { I Groups }\end{array}$ & $\begin{array}{l}\text { (J) Experimental } \\
\text { Groups }\end{array}$ & $\begin{array}{c}\text { Mean } \\
\text { Difference } \\
(\mathrm{I}-\mathrm{J})\end{array}$ & $\begin{array}{l}\text { Std. } \\
\text { Error }\end{array}$ & $Q$ & Sig. \\
\hline \multirow{6}{*}{$\begin{array}{l}\text { Direct } \\
\text { Recount } \\
\text { Text }\end{array}$} & \multirow[t]{2}{*}{$\begin{array}{l}\text { Factual } \\
\text { Recount }\end{array}$} & $\begin{array}{l}\text { Imaginative } \\
\text { Recount }\end{array}$ & $1.02222^{*}$ & $\begin{array}{r}.1250 \\
3\end{array}$ & -8.18 & $\begin{array}{r}.00 \\
1\end{array}$ \\
\hline & & $\begin{array}{l}\text { Students' } \\
\text { Experience }\end{array}$ & $1.96667^{*}$ & $\begin{array}{r}.1250 \\
3 \\
\end{array}$ & -15.73 & $\begin{array}{r}.00 \\
1 \\
\end{array}$ \\
\hline & \multirow[t]{2}{*}{$\begin{array}{l}\text { Imaginative } \\
\text { Recount }\end{array}$} & Factual Recount & $1.02222^{*}$ & $\begin{array}{r}.1250 \\
3\end{array}$ & 8.18 & $\begin{array}{r}.00 \\
1\end{array}$ \\
\hline & & $\begin{array}{l}\text { Students' } \\
\text { Experience }\end{array}$ & $-.94444^{*}$ & $\begin{array}{r}.1250 \\
3 \\
\end{array}$ & -7.55 & $\begin{array}{r}.00 \\
1 \\
\end{array}$ \\
\hline & \multirow[t]{2}{*}{$\begin{array}{l}\text { Students' } \\
\text { Experience }\end{array}$} & Factual Recount & $1.96667^{\star}$ & $\begin{array}{r}.1250 \\
3\end{array}$ & 15.73 & $\begin{array}{r}.00 \\
1 \\
\end{array}$ \\
\hline & & Imaginative Recount & $.94444^{*}$ & $\begin{array}{r}.1250 \\
3\end{array}$ & 7.55 & $\begin{array}{r}.00 \\
1\end{array}$ \\
\hline \multirow{6}{*}{$\begin{array}{l}\text { Indirect } \\
\text { Recount } \\
\text { Text }\end{array}$} & \multirow[t]{2}{*}{$\begin{array}{l}\text { Factual } \\
\text { Recount }\end{array}$} & $\begin{array}{l}\text { Imaginative } \\
\text { Recount }\end{array}$ & $\begin{array}{r}- \\
1.27407^{\star}\end{array}$ & $\begin{array}{r}.1242 \\
1\end{array}$ & -10.26 & $\begin{array}{r}.00 \\
1\end{array}$ \\
\hline & & $\begin{array}{l}\text { Students' } \\
\text { Experience }\end{array}$ & $2.30000^{-}$ & $\begin{array}{r}.1242 \\
1\end{array}$ & -18.52 & $\begin{array}{r}.00 \\
1\end{array}$ \\
\hline & \multirow[t]{2}{*}{$\begin{array}{l}\text { Imaginative } \\
\text { Recount }\end{array}$} & Factual Recount & $1.27407^{\star}$ & $\begin{array}{r}.1242 \\
1 \\
\end{array}$ & 10.26 & $\begin{array}{r}.00 \\
1 \\
\end{array}$ \\
\hline & & $\begin{array}{l}\text { Students' } \\
\text { Experience }\end{array}$ & $1.02593^{*}$ & $\begin{array}{r}.1242 \\
1\end{array}$ & -8.26 & $\begin{array}{r}.00 \\
1\end{array}$ \\
\hline & \multirow[t]{2}{*}{$\begin{array}{l}\text { Students' } \\
\text { Experience }\end{array}$} & Factual Recount & $2.30000^{\star}$ & $\begin{array}{r}.1242 \\
1\end{array}$ & 18.52 & $\begin{array}{r}.00 \\
1\end{array}$ \\
\hline & & Imaginative Recount & $1.02593^{\star}$ & $\begin{array}{r}.1242 \\
1 \\
\end{array}$ & 8.26 & $\begin{array}{r}.00 \\
1\end{array}$ \\
\hline
\end{tabular}

\section{Source: Data analysis of May 2019; SPSS 23}

1. Direct recount text about factual recount versus imaginative recount

Based on the results of the Post Hoc tests in the multiple comparisons table above, the mean difference score of direct recount text about factual recount and direct descriptive text about imaginative recount was $(-1.022)$. It meant that there was a significant difference of the effect of direct corrective feedback on the students' competency in writing recount text about factual recount and recount text about imaginative recount $(Q=-8.18 ; \alpha=0.01)$.

2. Direct recount text about factual recount versus students' experience

Based on the results of the Post Hoc tests in the multiple comparisons table above, the mean difference score of direct recount text about factual recount and direct recount text about students' experience was (-1.966). It meant that there was a significant difference of direct 
corrective feedback on the students' competency in writing recount text about factual recount and recount text about students' experience $(Q=-15.73 ; \alpha=0.01)$.

3. Direct recount text about imaginative recount versus students' experience

Based on the results of the Post Hoc tests in the multiple comparisons table above, the mean difference score of direct recount text about imaginative recount and direct recount text about students' experience was (-1.0255). It meant that there was a significant difference of direct corrective feedback on the students' competency in writing recount text about imaginative recount and recount text about students experience $(Q=-8.26 ; \alpha=0.01)$.

4. Indirect recount text about factual recount versus imaginative recount

Based on the results of the Post Hoc tests in the multiple comparisons table above, the mean difference score of indirect recount text about factual recount and indirect recount text about imaginative recount was $(-1.274)$. It meant that there was a significant difference of the effect of indirect corrective feedback on the students' competency in writing recount text about factual recount and recount text about imaginative recount $(Q=-10.26 ; \alpha=0.01)$.

5. Indirect recount text about factual recount versus students' experience

Based on the results of the Post Hoc tests in the multiple comparisons table above, the mean difference score of indirect recount text about factual recount and indirect recount text about students' experience was (-1.025). It meant that there was a significant difference of indirect corrective feedback on the students' competency in writing recount text about factual recount and recount text about students' experience $(Q=-18.52$.; $\alpha=0.01)$.

6 . Indirect recount text about imaginative recount versus students' experience

Based on the results of the Post Hoc tests in the multiple comparisons table above, the mean difference score of indirect recount text about imaginative recount and indirect recount text about students' experience was (-1.025). It meant that there was a significant difference of indirect corrective feedback on the students' competency in writing recount text about imaginative recount and recount text about students' experience $(Q=-8.26 ; \alpha=0.01)$.

Based on the result of table 6 above, it can be concluded that there were significant differences of the effects of direct and indirect corrective feedback on the students' competency in writing recount text about factual recount, imaginative recount, and students' experience. Besides, the most significant differences were found in recount text about students' experience. It clearly signified that direct and indirect worked well on the students' competency in writing recount texts. However, the result of the descriptive analysis showed that the direct corrective feedback gave more effect than indirect corrective feedback.

\section{CONCLUSION AND SUGGESTIONS}

Theoretically, the significant effects which were yielded in the present study were as the result of teaching techniques, direct and indirect corrective feedbacks. However, the effect of direct corrective feedback is more effective than indirect corrective feedback on the students' writing competency. This technique gives the students a chance to correct the errors themselves and understand how it should be written in their text. Seiffedin \& El-Sakka (2017) argues that direct feedback is more helpful to writers because it explicitly shows learners what is wrong and how it should be written correctly; minimizing students' confusion over teachers' feedback. Therefore, this type is more appropriate for student writers of low proficiency level who do not have the ability to self-correct their errors even when they are marked for them.

The result in the field also showed that the students treated by using direct corrective feedback made fewer errors. They already understood what they should write when they wrote a text. For example, when they wrote a descriptive text, they had to use the present tense. Moreover, if they wanted to retell something in the past they had to use the past tense. Direct corrective feedback also increases the students' competency in writing because the corrections and suggestions help the students in learning English. In addition, this technique also elicits students' autonomous learning. This conforms to the statement about direct corrective feedback. Therefore, direct corrective feedback has a more significant effect on the students writing competency compared to indirect corrective feedback.

Furthermore, direct corrective feedback has more effective than indirect corrective feedback on the students' writing competency because it provides the correct form that allows 
them to learn English, especially how to write. Provision of the correct form after doing a correction decreases the students' misperceptions about the meaning of the correction itself. It is completely different from indirect correction which does not provide the correct form. It only gives a correction by underlining the errors and let the students correct themselves. This way makes the students feel confused about what they should write after being given the correction.

Empirically, the result of the present study is also in line with some research which has already been carried. For example, Almasi (2016) in his research who found out that direct corrective feedback was more effective in reducing students' errors on grammatical items focused in the study, not only in subsequently revised writing but also in the production of new writing. Besides, Aghajanloo (2016) also confirmed that the students' achievement in writing improved after the implementation of direct corrective feedback. These two researchers clearly showed that direct corrective feedback was really effective in improving the students' writing competency, especially in writing descriptive and recount text.

The eighth-grade students of SMP Negeri 2 Manggis who were chosen as the samples in the present experimental research showed that the grand score of direct corrective feedback group which was higher than that of the indirect corrective feedback group. In group I which was treated through the application of direct corrective feedback, there were a lot of students who felt confident when asked to write a text. The treatment was easy to understand and easy to remember because they corrected their writing after the treatment. So that is the way they were really motivated in learning English especially writing. It was completely different from group II which was treated through indirect corrective feedback, they tended to feel confused with the correction given because indirect corrective feedback only gave a correction by underlining the student's error in writing but not provide the correct form. Only high achiever students who understood the correction given.

To sum up, direct corrective feedback was more effective on the students' writing competency and it has been theoretically and empirically proven. The present empirical research also proved that there were significant differences of the effects of direct and indirect corrective feedback on the students' competency across descriptive texts and recount texts especially in writing a descriptive text about place and recount text about students' experience. However, the effect of direct corrective feedback was more effective than the effect of indirect corrective feedback on the students' competency across descriptive texts and recount texts. The result showed that there was a significant effect of the used of grammar in writing texts especially when they wrote a descriptive text about place and recount text about students' experience. This greatly effects on the students' competency in writing a text especially when they used the present verb and when they used the past verb in the sentences that they made. On the other hand, the students really interested when they were asked to describe about place, they really enjoy sharing their ideas when they asked to describe their favorite place that they always visit. The use of grammar also different when they wrote a recount text about students' experience than when they asked to write about factual and imaginative recount. The grammar usage is better when they asked to retell their experience.

In accordance with the research findings which have already been discussed previously, the present experimental research was designed by using quasi-experimental design. The conclusion of the present experimental research can be briefly elaborated as follows:

1. Based on the descriptive and inferential analysis, there were significant effects of direct corrective feedback and that of indirect corrective feedback on the students' writing competency $(F=197.3 ; \alpha=0.01$. It was lower than 0.05 . It meant that there were significant. However, the calculation showed that direct corrective feedback had a more effect on the students' writing competency than that indirect corrective feedback.

2. There were statistically significant differences of the effects of the use of direct corrective feedback and that of indirect corrective feedback on students' competency in writing descriptive texts. The analysis showed that there were significant effects of direct and indirect corrective feedback on students' competency in writing descriptive texts ( $F=277.6 ; \alpha=0.01$. It was lower than 0.05. It meant that there were significant differences. The Multiple Comparison using Tukey HSD figured out that the effects of the implementation of direct and indirect corrective feedbacks gave significant differences on the students' competency in 
writing descriptive texts. Besides, the most significant differences were found in the descriptive text about place. It clearly signified that direct and indirect worked well on the students' competency in writing descriptive texts. However, the result of the descriptive analysis showed that direct corrective feedback gave more effect than indirect corrective feedback.

3. There were statistically significant differences in the effects of direct and indirect corrective feedback on students' competency in writing recount texts. The analysis showed that there were significant differences in the effects of direct corrective feedback and indirect corrective feedback on students' competency in writing recount texts $(F=292.4 ; \alpha=0.01$. It was lower than 0.05 . It meant that there were significant differences. The Multiple Comparison using Tukey HSD figured out that the effects of the implementation of direct and indirect corrective feedbacks gave significant differences on students' competency in writing recount texts. Besides, the most significant differences were found in recount text about students' experience. It clearly signified that direct and indirect worked well on the students' competency in writing descriptive texts. However, the result of the descriptive analysis showed that the direct corrective feedback gave a more effect on students' competency in writing recount texts than indirect corrective feedback.

Based on the finding of the present experimental research, which have already concluded, the researcher would like to give some suggestions which are in line with the area of the present research. The suggestions are as follows:

1. It is recommended to English teachers, particularly who teach the eighth-grade of SMP Negeri 2 Manggis to implement direct corrective feedback as an alternative teaching technique in teaching English writing.

2. It is hoped that the result of the present study is able to give a contribution to the Ganesha University of Education as a relevant reference which supports the graduate program.

3. The result of the study is also expected to be a strong relevant reference for other researchers in selecting relevant conflicting topics and different participants.

4. This research restrictedly focused on the writing competency. It would be meaningful to examine whether direct corrective feedback and indirect corrective feedback could successfully be used for other language skills both receptive and productive language skills.

\section{REFERENCES}

Aghajanloo, K. (2016). The Effect of Teachers' Written Corrective Feedback (WCF) Types on Intermediate EFL Learners' Writing Performance. Advances in Language and Literary Studies, 7(3). https://doi.org/10.7575/aiac.alls.v.7n.3p.28

Almasi, E. (2016). The Effects of Direct vs Indirect Corrective Feedback on Iranian EFL Learners 'Writing Accuracy. Journal of Applied Linguistics and Language Research, 3(1), 74-85.

Aridah. (2016). The Effectiveness of Direct and Indirect Written Corrective Feedback in Efl Writing Performance. Proceedings of the Fourth International Seminar On English Language and Teaching (ISELT-4), (2013), 105-115.

Campbell, D. T., \& Stanley, J. C. (1985). Experimental and Quasi-Experimental Design for Research. (N. L. Gage, Ed.). U.S.A.

Candiasa. I. M. (2011). Pengujian Instrument Penelitian Disertai Aplikasi dengan Item, Bigsteps dan SPSS. Singaraja: Unit Penerbit Universitas Pendidikan Ganesha

Damayanti, G. A. T. (2017). The Effect of Indirect Corrective Feedback on Students 'Writing of Descriptive Text. Department of English Education Faculty of Educational Sciences State Islamic University Syarif Hidayatullah Jakarta

Eslami, E. (2014). The Effects of Direct and Indirect Corrective Feedback Techniques on EFL Students ' Writing. Procedia - Social and Behavioral Sciences, 98, 445-452. https://doi.org/10.1016/j.sbspro.2014.03.438 
Gronlund, N. (1985). Measurement and Evaluatiom in Teaching. MacMillan, New York.

Hinkle, et. al. (1979). Applied Statistics for the Behavioral Sciences. Booston, MA: Honghton Mifflin Company.

Khodareza, M., \& Delvand, S. A. (2016). The Impact of Written Corrective Feedback of Grammatical Points on Iranian Efl Learners. Online International Journal Available at www.cibtech.org/sp.ed/jls/2016/01/jls.htm 2016 Vol. 6 (S1), pp. 470-475

Maleki, A., \& Eslami, E. (2013). The Effects of Written Corrective Feedback Techniques o $n$ EFL Students " Control over Grammatical Construction of Their Written, 3(7), 1250-1257. https://doi.org/10.4304/tpls.3.7.1250-1257

Seiffedin, A. H. (2017). The Impact of Direct-indirect Corrective E- feedback on EFL Student s 'Writing Accuracy, (March). https://doi.org/10.17507/tpls.0703.02

Seiffedin, A. H., \& El-Sakka, S. M. F. (2017). The Impact of Direct-indirect Corrective Efeedback on EFL Student S ' Writing Accuracy, 7(3), 166-175.

Sermsook, K., Liamnimitr, J., \& Pochakorn, R. (2017). The Impact of Teacher Corrective Feedback on EFL Student Writers' Grammatical Improvement. English Language Teaching, 10(10), 43. https://doi.org/10.5539/elt.v10n10p43

Shirotha, F. B. (2016). Journal on English as a Foreign Language The Effect of direct Written Corrective Feedback on Students ', 6(2), 101-118. 